\title{
Molecular description and similarity relationships among native germplasm potatoes (Solanum tuberosum ssp. tuberosum L.) using morphological data and AFLP markers
}

\author{
Jaime Solano Solis \\ Laboratorio de Biotecnología y Mejoramiento Vegetal \\ Escuela de Agronomía \\ Universidad Católica de Temuco \\ Longitudinal Norte s/n Temuco, Chile \\ Tel: 5645205527 \\ Fax: 5645205540 \\ E-mail: jsolano@uct.cl \\ Daniza Morales Ulloa \\ Laboratorio de Biotecnología y Mejoramiento Vegetal \\ Escuela de Agronomía \\ Universidad Católica de Temuco \\ Longitudinal Norte s/n Temuco, Chile \\ Tel: 5645205527 \\ Fax: 5645205540 \\ Leonardo Anabalón Rodríguez* \\ Laboratorio de Biotecnología y Mejoramiento Vegetal \\ Escuela de Agronomía \\ Universidad Católica de Temuco \\ Longitudinal Norte s/n Temuco, Chile \\ Tel: 5645205527 \\ Fax: 5645205540 \\ E-mail: lanabalo@uct.cl
}

Financial support: The present work has been done in the framework of a research programme DIPUCT (Grant DIPUCT 2004-2-02) of the Universidad Católica de Temuco.

Keywords: cluster analysis, molecular markers, Solanum tuberosum ssp. tuberosum.

Abbreviations: AFLP: amplified fragment length polymorphism PCR: polimerase chain reaction

Chile is considered to be a sub-center of origin for the cultivated potato, with native and introduced genetic material coexisting in the country. Thus, the different varieties present in Chiloe Island are characterized by a rich diversity of forms, sizes, colours and phenological characteristics. In the present work, the level of polymorphism and the genetic relationship were studied by means of molecular markers using the amplified fragment length polymorphism (AFLP) technique and twenty-seven morphological characters. Twenty varieties of potatoes from the Chiloe Island were analyzed. The commercial variety Desirée and one specie from the Etuberosa series, Solanum fernandezianum, collected in the Juan Fernandez Island were included as controls. A similarity tree-diagram was made, based on all the AFLP bands generated in the range between 65 and 290 base pairs. With these tools, it was possible to identify molecular differences and similarities that might be associated with important morphological traits such as the predominant forms of the tuber, flower colour and resistance to disease.

The potato is one of the four most important crops in the country and constitutes a basic food in the diet of the population. Chile is considered to be a sub-center of origin for the cultivated potato (Spooner et al. 2005b). In this context, the native potatoes of Chiloe are characterized by a rich variety of forms, sizes, colours and phenological characteristics. This rich genetic patrimony needs to be described and individualized in order to be conserved and used. Unfortunately, more of the native potatoes of Chiloe are being lost every day, because of their replacement by introduced varieties and their phytopathological deterioration among other causes. As a result, their conservation must be ensured by means of germplasm banks collections. The conservations and use of this native genetic material will ensure that it does not disappear, but

*Corresponding author 
Table 1. Accessions included in the analysis.

\begin{tabular}{|c|c|c|c|c|c|}
\hline$\underset{N^{\circ}}{\text { Sample }}$ & Accession & Common name & Specie & Location & Material \\
\hline 1 & UCT1Ma & Michuñe azul & S. tuberosum & Island of Chiloe & Tuber \\
\hline 2 & UCT2LV & Lengua vaca & S. tuberosum & Island of Chiloe & Tuber \\
\hline 3 & UCT3Cl & Clavela & S. tuberosum & Los muermos & Tuber \\
\hline 5 & UCT5De & Desireé & S. tuberosum & Temuco, Huichahue & Tuber \\
\hline 6 & UCT6Gc & Guadacho colorado & S. tuberosum & Island of Chiloe & Tuber \\
\hline 7 & UCT7Ca & Camota & S. tuberosum & Island of Chiloe & Tuber \\
\hline 8 & UCT8Gb & Guadacho blanco & S. tuberosum & Island of Chiloe & Tuber \\
\hline 9 & UCT9MgM & Meca gato Morada & S. tuberosum & Island of Chiloe & Tuber \\
\hline 10 & UCT10MgL & $\begin{array}{l}\text { Meca gato } \\
\text { morada larga }\end{array}$ & S. tuberosum & Los Muermos & Tuber \\
\hline 11 & UCT11Mgb & Meca gato blanca & S. tuberosum & Island of Chiloe & Tuber \\
\hline 12 & UCT12Co & Coktail & S. tuberosum & Island of Chiloe & Tuber \\
\hline 13 & UCT13MpB & Meca gato morada puntos blancos & S. tuberosum & Island of Chiloe & Tuber \\
\hline 14 & UCT14MgRe & Meca gato redonda & S. tuberosum & Los Muermos & Tuber \\
\hline 15 & UCT15MgRo & Meca gato roja & S. tuberosum & Island of Chiloe & Tuber \\
\hline 16 & UCT16At & Azul tabla & S. tuberosum & Island of Chiloe & Tuber \\
\hline 17 & UCT17Br & Bruja & S. tuberosum & Island of Chiloe & Tuber \\
\hline 18 & UCT18Mn & Michuñe negro & S. tuberosum & Island of Chiloe & Tuber \\
\hline 19 & UCT19Aq & Azul de Quento & S. tuberosum & Island of Chiloe & Tuber \\
\hline 20 & UCT20Ro & Rosada & S. tuberosum & Island of Chiloe & Tuber \\
\hline 21 & UCT21AC & Azul cristalina & S. tuberosum & Island of Chiloe & Tuber \\
\hline 22 & UCT22Cm & Clavela morada & S. tuberosum & Island of Chiloe & Tuber \\
\hline 23 & UCT23Sf & & S. fernandezianum & $\begin{array}{c}\text { Island Juan Fernandez } \\
\text { Plazoleta Yunque }\end{array}$ & $\begin{array}{l}\text { Botanical } \\
\text { seed }\end{array}$ \\
\hline
\end{tabular}

enjoys a projection for the future with new uses. In addition, potato improvement programs require a basic knowledge of the morphology and genetic nature of the main parts of the plant. In this context, new advances in molecular biology with the use of more sensitive molecular markers able to detect changes in the genotype of the individuals, greatly contributed to the generation of this important information.

There is a remarkable concentration of cultivated and wild forms of potato in the south of Chile with the greatest number of native varieties being located in the island of Chiloe, and they are still preserved in the fields of small farmers. The peculiar characteristics of Chiloe, its natural conditions and its isolation, have allowed the proliferation of a great number of native varieties, of varying qualities and suitable for cultivation at different times in the farming calendar, as well as a number of different forms of preparation and consumption (Contreras et al. 1981). Until the mid 1960s, the markers used in genetic studies and improvement were those controlled by genes associated with morphological characteristics in easily identified phenotypes (Hijmans and Spooner, 2001). Potato germplasm has been described using morphological elements (Huamán et al. 1977; Ortiz and Huamán, 1994). Since 1975, it has been known in Europe and North America that potato cultivars could be identified by their protein and enzyme patterns (Stegemann and Loeschecke,
1976). With the modern technologies provided by molecular biology, various methods arise for the direct detection of genetic polymorphism at the DNA level using molecular markers. Molecular markers have contributed to a greater genetic knowledge of many vegetable species, including potato (Ritter et al. 2004). In addition, these markers have been used in the Solanum genus for the

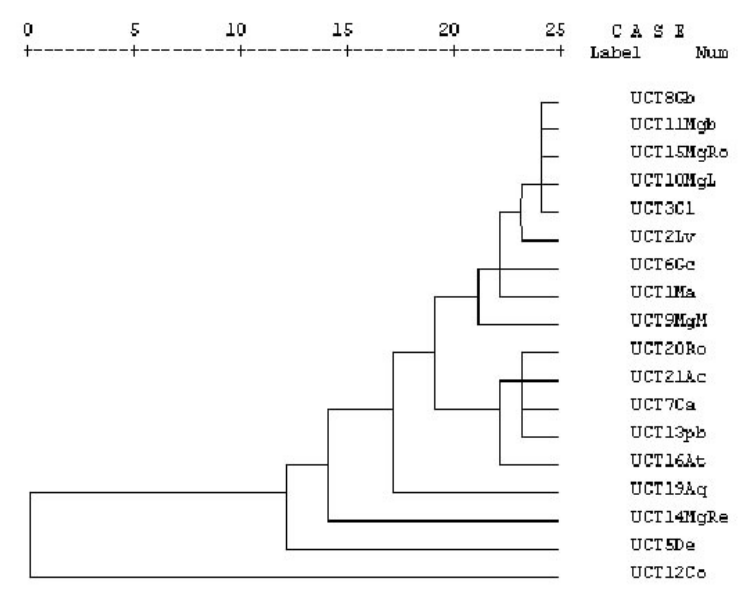

Figure 1. Dendrograms of native germplasm potatoes using morphological data. 
analysis of biodiversity and for phylogenetic studies (Ritter, 2000; Spooner et al. 2005a). Recently, efforts have been devoted to achieve a less subjective description of cultivars, based on Random Amplified Polymorphic DNA (RAPD) (Miller and Spooner, 1999; Isenegger et al. 2001; Sun et al. 2003), and microsatellites (Ashkenazi et al. 2001; Raker and Spooner, 2002). Interrupted Simple Sequence Repeats (ISSR) has also been used (Milbourne et al. 1998; Bornet et al. 2002). Amplified fragment length polymorphism (AFLP) analysis represents the most recent technology for obtaining a great number of molecular markers in the genomes of prokaryotes and eukaryotes (Savelkoul et al. 1999). The AFLP technique (Vos et al. 1995) generally produces between 50 and 100 scorable fragments per polimerase chain reaction (PCR) reaction (Maughan et al. 1996). This technique has been widely used in various crops, including cultivated potatoes (Powell et al. 1996; Milbourne et al. 1997; McGregor et al. 2000; Avrova et al. 2002; Straadt and Rasmussen, 2003; Furini and Wunder, 2004) and their wild relatives (Kardolus et al. 1998). In the last years, the AFLP technology was used to differentiate genotypes used as ancestors in potato genetic improvement programs. This allowed establish exactly the differences between the most important varieties used in these programs. In this context, Spooner et al. (2005b) used AFLP molecular data, suggest a single origin rather than multiple origins of cultivated potato.

In this paper, we have analyzed the molecular diversity of Chilean native potato germplasm (Solanum tuberosum ssp. tuberosum L.) using AFLP markers and determined the genetic relationships existing among the genotypes included in the study.

\section{MATERIALS AND METHODS}

\section{Plant material}

The analysis included twenty accessions of native potato collected on the island of Chiloe, one improved cultivar Desirée, and one accession from the Etuberosa series, Solanum fernandezianum collected in the Juan Fernandez Island, Chile. Accessions were chosen to represent the extensive genetic diversity that can be found in Solanum tuberosum (Table 1). This material was cultivated in the field during agricultural season 2003/2004. The culture in the field began October 2003 and ended with the harvest in May 2004. The varieties were planted to $80 \mathrm{~cm}$

Table 2. Descriptive names of the 27 morphological characters examined.

\begin{tabular}{|c|c|}
\hline The descriptor list & Morphological Characters \\
\hline \multirow{2}{*}{ Plant } & Growth habit type \\
\hline & Plant Height at flowering stage \\
\hline \multirow{11}{*}{ Tuber } & General tube shape \\
\hline & Unusual tuber shape \\
\hline & Predominant tuber skin colour \\
\hline & Secondary tuber skin colour \\
\hline & Distribution of secondary tuber colour \\
\hline & Tuber skin type \\
\hline & Predominant tuber flesh colour \\
\hline & Secondary tuber flesh colour \\
\hline & Distribution of secondary tuber flesh colour \\
\hline & Depth of tuber eyes \\
\hline & Note of eyes per tuber \\
\hline \multirow{2}{*}{ Leaf } & Abaxial leaf pubescent \\
\hline & Adaxial leaf pubescent \\
\hline \multirow{3}{*}{ Stems } & Number of the primary stem \\
\hline & Stem colour \\
\hline & Stem cross section \\
\hline \multirow{4}{*}{ Phenology } & Day to formation of the first floral button \\
\hline & Day at beginning of flowering \\
\hline & Day at beginning of berry formation \\
\hline & Day to harvest maturity \\
\hline \multirow{3}{*}{ Flower } & Calix colour \\
\hline & Predominant flower colour \\
\hline & Secondary flower colour \\
\hline \multirow{3}{*}{ Fruit } & Fruit colour \\
\hline & Number of fruits \\
\hline & Fruition presence \\
\hline Disease reaction data & Evaluation to potato late blight (Phytophthora infestans) \\
\hline
\end{tabular}


between and $40 \mathrm{~cm}$ over the crop line. An experimental design of complete blocks in random order was used in the establishment of the varieties in the field, in which the treatments corresponded to the different varieties being evaluated.

\section{Morphological characters analysis}

Twenty-seven characters, analyzed and described by Huamán et al. (1977) using potatoes varieties, and applied to "Chilean or native" varieties were numerically codified using a qualitative multi-status criteria (from 0 to 9, depending on the variables of each character). These were used to design a numbered-data matrix. Some characters included in this analysis were (Table 2): predominant tuber skin colour, general tuber shape, leaf characters, flower and fruit characters, phenologic data and reaction to fungi (Phytophtora infestans). Ten individuals were morphologically evaluated in each variety.

The morphologic data were subjected to cluster analysis. A standardization of the data by means of the Z-scores function was made. Average was applied to the technique of hierarchical conglomerate linkage using a matrix of quadratic similarity by means of Euclidean distances. The clustering method was made using the statistical software SPSS (statistical product and service solutions) version 12.0 for windows. S. fernandezianum was not included since it is a non-bearing species. Bruja, Michuñe negra and Clavela morada were not included because none of them bloomed and therefore several characters related to flowering and fructification could not be sufficiently registered.

\section{DNA isolation}

Approximately 100-200 mg of leaf tissue were freeze-dried and ground in liquid nitrogen with a mortar and pestle. Genomic DNA was isolated with Plant DNAzol ${ }^{\circledR}$ following the manufacturer's instructions. RNA was further eliminated by treatment with RNase. The quality and concentration of DNA was evaluated by agarose gel

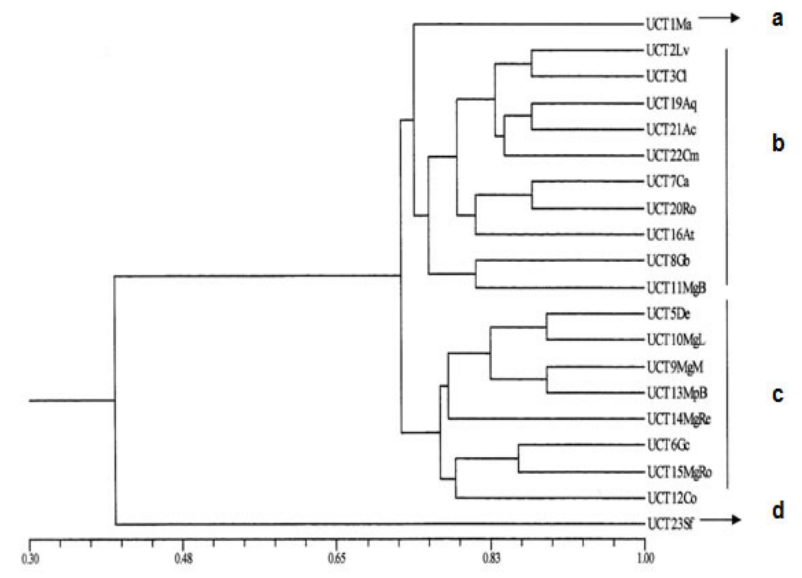

Figure 2. A similarity tree-diagram produced by UPGMA analysis of AFLP data.

electrophoresis and spectrophotometry. Two independent extractions were performed on each accession.

\section{AFLP analysis}

AFLP reactions were carried out using the AFLP Analysis System I kit (Invitrogen Life Technologies) according to the manufacturer's instructions. Each reaction was repeated at least once to verify the AFLP patterns generated.

Approximately $500 \mathrm{ng}$ of genomic DNA was digested for 2 hrs at $37^{\circ} \mathrm{C}$ using $2 \mathrm{ul}$ Eco RI/MseI restriction enzyme solution. The AFLP procedure (Vos et al. 1995) was carried out as described by Arens et al. (1998) with slight modifications. Briefly, the entire genomic DNA (400-500 ng) was digested with EcoRI and MseI, followed by ligation of the adapters. Pre-amplification was performed using a single adenine (A) selective nucleotide for each primer. For selective amplification, an EcoRI primer, with three selective nucleotides, was used in combination with a MseI primer with three selective nucleotides. For both the

Table 3. Primer combinations used and polymorphic bands generated.

\begin{tabular}{|c|c|c|c|c|}
\hline Primer combination & $\mathbf{N}^{\circ}$ of bands & $\begin{array}{c}\mathbf{N}^{\circ} \text { of monomorphic } \\
\text { bands }\end{array}$ & $\begin{array}{c}\mathbf{N}^{\circ} \text { polymorphic } \\
\text { bands }\end{array}$ & $\begin{array}{c}\text { \% of polymorphic } \\
\text { bands }\end{array}$ \\
\hline EcoRI-ACC /Msel-CAT & 66 & 0 & 66 & 100 \\
\hline EcoRI-AGG /Msel-CTT & 34 & 8 & 26 & 76.47 \\
\hline EcoRI-AAG /Msel-CAC & 56 & 9 & 47 & 83.93 \\
\hline EcoRI-ACC /Msel-CAA & 48 & 5 & 43 & 89.58 \\
\hline EcoRI-ACA /Msel-CTG & 77 & 6 & 71 & 92.21 \\
\hline TOTAL & 281 & 28 & 253 & 90.04 \\
\hline & & $9.96 \%$ & $90.04 \%$ & \\
\hline
\end{tabular}


pre-amplification and selective amplification the following amplification profile was used: an initial cycle of $94^{\circ} \mathrm{C}$ for $30 \mathrm{sec}, 65^{\circ} \mathrm{C}$ for $30 \mathrm{sec}, 72^{\circ} \mathrm{C}$ for $1 \mathrm{~min}$, followed by 12 touchdown cycles in which the annealing temperature was reduced by $0.7^{\circ} \mathrm{C}$ per cycle. The annealing temperature was then kept constant at $56^{\circ} \mathrm{C}$ for the remaining 23 cycles. Amplification products were separated on a $6 \%$ polyacrylamide gel, and made visible by silver staining. Twenty-three primer combinations were tested for their ability to generate reproducible AFLP profiles that could be scored unambiguously. Reproducibility of the primer combinations was tested by comparing the AFLP profiles of four DNA samples collected from the same individual. Five combinations were specifically chosen for their ability to generate a large number of bands in order to increase resolution for the identification of possible identical plants (Table 2).

For each primer combination, the presence or absence of a band in each sample was visually scored. Data were set in a binary matrix (Paul et al. 1997; Yee et al. 1999). Genetic similarities were calculated using the similarity coefficient and tree-diagrams obtained by clustering according to the unweighted pair group method with arithmetic averages (UPGMA) method using the NTSYS (numerical taxonomy and multivariate analysis system) pc 2.0.1 program (Applied Biostatistics Inc., NY, USA). The correspondence between the morphological and AFLP similarity coefficient matrices was tested on the basis of correlation analysis for
Mantel test using the Mxcomp procedure.

\section{RESULTS AND DISCUSSION}

\section{Morphological data}

The morphologic data cluster analysis allowed the separation of two defined groups (Figure 1). The first group included potatoes with semi late vegetative cycle and elongate tubers, and skins of coloration dark purple. The stems of this group present angular sections and green colours and node of reddish and purples colours. The flowers show an intense red colour. Some varieties included in this are UCT8Gb, UCT11Mgb, UCT15MgRo, UCT6Gc, UCT9MgM and UCT1Ma. The second group presented semi early cycle and tubers of round forms, with skins principally purple colour and secondary white colour, distributed through all tuber or located around the eyes. This material presented dark green stems of angular sections and flowers intensely purple. This group was formed by the accessions UCT7Ca, UCT13MpB, UCT20Ro, UCT21Ac and UCT16At. Four accessions were not integrated in any of the previous groups. These are UCT19Aq, UCT5De, UCT14MgRe and UCT12Co, which morphologically are different. Comparatively these were less erect, more branchingand smaller plant. Their tubers were predominantly oval-elongate to round, with a greater number of principal stems by plant and a clear dominion of flowers of white coloration.

Table 4. Genetic similarity values of potato native varieties using SM coefficient with AFLP markers.

\begin{tabular}{|c|c|c|c|c|c|c|c|c|c|c|c|c|c|c|c|c|c|c|c|c|}
\hline Accession & $\begin{array}{l}\text { UCT } \\
1 \mathrm{Ma}\end{array}$ & $\begin{array}{l}\text { UCT } \\
2 \mathrm{LV}\end{array}$ & $\begin{array}{l}\text { UCT } \\
\text { 3CI }\end{array}$ & $\begin{array}{l}\text { UCT } \\
5 \mathrm{De}\end{array}$ & $\begin{array}{l}\text { UCT } \\
\text { 6GC }\end{array}$ & UCT & $\begin{array}{l}\text { UCT } \\
8 G b\end{array}$ & $\begin{array}{c}\text { UCT } \\
9 \\
\text { MgM }\end{array}$ & $\begin{array}{c}\text { UCT } \\
10 \\
\text { MgL }\end{array}$ & $\begin{array}{c}\text { UCT } \\
11 \\
\text { Mgb }\end{array}$ & $\begin{array}{l}\text { UCT } \\
12 \text { Co }\end{array}$ & $\begin{array}{c}\text { UCT } \\
13 \\
\text { MpB }\end{array}$ & $\begin{array}{c}\text { UCT } \\
14 \\
\text { MgRe }\end{array}$ & $\begin{array}{c}\text { UCT } \\
15 \\
\text { MgRo }\end{array}$ & $\begin{array}{l}\text { UCT } \\
\text { 16At }\end{array}$ & $\begin{array}{l}\text { UCT } \\
19 A q\end{array}$ & $\begin{array}{l}\text { UCT } \\
\text { 20Ro }\end{array}$ & $\begin{array}{l}\text { UCT } \\
21 A C\end{array}$ & $\begin{array}{c}\text { UCT } \\
22 \mathrm{Cm}\end{array}$ & $\begin{array}{l}\text { UCT } \\
23 S f\end{array}$ \\
\hline UCT1Ma & 1 & & & & & & & & & & & & & & & & & & & \\
\hline UCT2LV & 0,79 & 1 & & & & & & & & & & & & & & & & & & \\
\hline UCT3CI & 0,79 & 0,88 & 1 & & & & & & & & & & & & & & & & & \\
\hline UCT5De & 0,74 & $|0,80|$ & 0,80 & 1 & & & & & & & & & & & & & & & & \\
\hline UCT6Gc & 0,79 & 0,82 & 0,79 & 0,74 & 1 & & & & & & & & & & & & & & & \\
\hline UCT7Ca & 0,76 & 0,88 & 0,79 & 0,77 & 0,82 & 1 & & & & & & & & & & & & & & \\
\hline UCT8Gb & 0,74 & 0,77 & 0,83 & 0,73 & 0,71 & 0,71 & 1 & & & & & & & & & & & & & \\
\hline UСT9MgM & 0,73 & 0,73 & 0,70 & 0,83 & 0,79 & $\mid 0,76$ & 0,71 & 1 & & & & & & & & & & & & \\
\hline UCT10MgL & 0,67 & 0,76 & 0,73 & 0,89 & 0,73 & 0,76 & 0,74 & 0,85 & 1 & & & & & & & & & & & \\
\hline UCT11Mgb & 0,65 & 0,74 & 0,77 & 0,79 & $|0,77|$ & 0,80 & 0,82 & 0,80 & 0,83 & 1 & & & & & & & & & & \\
\hline UCT12Co & 0,70 & 0,73 & 0,70 & 0,77 & $|0,76|$ & 0,79 & 0,68 & 0,79 & 0,79 & 0,77 & 1 & & & & & & & & & \\
\hline UCT13MpB & 0,74 & $|0,65|$ & 0,68 & 0,82 & $|0,74|$ & 0,68 & $|0,67|$ & 0,89 & 0,83 & $\mid 0,76$ & 0,77 & 1 & & & & & & & & \\
\hline UCT14MgRe & 0,73 & $\mid 0,79$ & 0,79 & 0,80 & $|0,76|$ & $\mid 0,76$ & 0,71 & 0,79 & 0,79 & $|0,77|$ & 0,79 & 0,77 & 1 & & & & & & & \\
\hline UCT15MgRo & 0,68 & $|0,71|$ & 0,68 & 0,76 & $|0,86|$ & $|0,77|$ & $|0,67|$ & 0,89 & $|0,77|$ & $\mid 0,79$ & 0,83 & 0,82 & 0,77 & 1 & & & & & & \\
\hline UCT16At & 0,77 & $\mid 0,86$ & 0,80 & 0,76 & $|0,77|$ & 0,86 & 0,76 & 0,71 & 0,74 & 0,73 & 0,74 & 0,64 & 0,77 & 0,73 & 1 & & & & & \\
\hline UCT19Aq & 0,76 & 0,85 & 0,85 & 0,74 & 0,76 & 0,76 & $\mid 0,77$ & 0,67 & 0,73 & 0,74 & 0,67 & 0,65 & 0,76 & 0,65 & 0,74 & 1 & & & & \\
\hline UCT20Ro & 0,76 & 0,82 & 0,76 & 0,74 & $\mid 0,76$ & 0,88 & 0,71 & 0,73 & 0,76 & 0,77 & 0,76 & 0,71 & 0,73 & 0,71 & 0,77 & 0,76 & 1 & & & \\
\hline UCT21AC & 0,76 & 0,82 & 0,85 & 0,80 & 0,73 & 0,79 & 0,80 & 0,70 & 0,79 & 0,80 & 0,70 & 0,68 & 0,76 & 0,65 & 0,74 & 0,88 & 0,79 & 1 & & \\
\hline UCT22Cm & 0,74 & 0,83 & 0,83 & 0,73 & $|0,80|$ & $0,83 \mid \mathrm{C}$ & $\mid 0,76$ & 0,74 & $|0,77|$ & 0,79 & 0,77 & 0,70 & 0,77 & 0,73 & 0,82 & 0,83 & 0,83 & 0,86 & 1 & \\
\hline UCT23Sf & 0,45 & 0,42 & 0,39 & 0,41 & 0,39 & $0,48 \mid$ & 0,44 & 0,39 & 0,39 & 0,44 & 0,36 & 0,41 & 0,36 & 0,32 & 0,50 & 0,42 & 0,52 & 0,48 & 0,47 & \\
\hline
\end{tabular}




\section{AFLP data}

The DNA samples were amplified with five primer combinations generating 281 AFLP markers positions, of which 253 (90.04\%) were polymorphic (Table 3). The number of polymorphic markers per primer varied from 26 to 71. Primer pair EcoRI-ACC /MseI-CAT contributed the highest number of profiles obtaining $100 \%$ of polymorphic bands. These results concurred with those obtained by Savelkoul et al. (1999), who indicated that analysis using AFLP markers ensured a high level of polymorphic bands.

Furthermore, these results agree with those reported by Kim et al. (1998), who obtained a total of 84 polymorphic bands using a single primer combination among 12 potato cultivars. McGregor et al. (2002) indicate that AFLP is a very informative technique for difference potato germplasm, since they obtained 130 polymorphic DNA bands from two pair of combinations. Different combinations of primers achieved different degree of efficiency in the detection of polymorphism (Table 3). It was observed that the combination EcoRI-AGG/MseI-CTT displayed the lowest efficiency in the detection of polymorphisms with just 26 polymorphic bands (76.47\%). The most efficient combination was EcoRI-ACC/MseICAT, which detected a total of 66 polymorphic bands (100\%). Rouppe van der Voort et al. (1998), report that only one combination revealed sufficient information in an analysis of five genotypes of potato. These authors add that the number of monomorphic AFLP markers increases with the number of combinations of primers evaluated and the number of genotypes analyzed. Nevertheless, using different restriction enzymes, different pre-selective and selective nucleotide combinations increase the probability of finding useful polymorphisms; however, a greater number of selective bases lower the detection of polymorphisms. Our results indicated that all the matches analyzed differ in their degrees of similarity. The accessions "UCT5De" and "UCT10MgL" presented the highest genetic similarity (0.89), likewise the accessions "UCT9MgM" and "UCT13MpB" (Table 4). With respect to the accessions from Chiloe, the one, which displayed the least similarity to the rest, was "UCT1Ma". On the other hand, when comparing all accessions included in the study, it appears that they presented on average high genetic diversity $(0,73)$ with similarities ranging between 0,32 and 0,89 (Table 4).

The similarity tree-diagram (Figure 2) derived from the register of all AFLP bands was generated by the use of combinations ACC/CAT, AGG/CTT, ACC/CAT, AAG/CAC and ACA/CTG. Nevertheless a single combination of primers (ACC/CAT) was sufficient to establish a level of optimal polymorphism. Four clusters were defined from the cluster analysis. The first cluster included only the accession UCT1Ma (a) (common name "michuñe azul"), which has a strongly restricted fusiform tuber of an intense blue colour. The second group (b) corresponded to tuber potatoes which have a generally oval form and a light-coloured skin, some with the presence of secondary colours. The flowers of this group are blue or pale-blue in colour. The third group (c) was made up of varieties which are long and smooth in shape, with strong pigmentation. This group presented flowers with strong colours, predominantly purple and intense red. Finally, the last group included the control diploid species, Solanum fernandezianum (d), which confirms the fact that this species belongs to the Etuberosa series.

\section{Comparison between morphological and AFLP data}

The Mantel test showed quite low correlations between the morphological and the molecular (AFLP) dendograms obtained $(r=-0,09)$. Both the morphological and genetic analysis allowed to separate defines groups of native potato germplasm. No significant concordance between AFLP and morphology cluster analyses was observed. In the morphologic analysis, the commercial variety Desiree appeared like an independent variety whereas in the AFLP analysis it integrated group c. The morphological traits of this group are not present in variety Desiree; however, AFLP data indicating that exists a high similarity with the native material of potato of the Chilote group. This result agrees with the hypothesis of the existence of ancestral genes in improvement cultivars of potato. This absence of concordance also has been observed by Xu et al. (2000), Federici et al. (2001), Roldán-Ruiz et al. (2001), Martínez et al. (2003), in varieties of grapevines, weedy rice, ryegrass and azuki beans respectively. Finally, Spooner et al. (2005b), report that techniques of DNA fingerprinting are better than morphological data for discrimination of related genotypes and in the analysis of the genetic similarity. Our results confirm that DNA analysis by AFLP is an efficient method for the exploration of genetic diversity in potato populations. According to our background this is the first study using AFLP markers in Chile to assess the great variability that existing among Chilean germplasm of potato.

\section{REFERENCES}

ARENS, P.; COOPS, H.; JANSEN, J. and VOSMAN, B. Molecular genetic analysis of black poplar (Populus nigra L.) along Dutch rivers. Molecular Ecology, January 1998, vol. 7, no. 1, p. 11-18.

ASHKENAZI, Varda; CHANI, Eduard; LAVI, Uri; LEVY, David; HILLEL, Jossi and VEILLEUX, Richard E. Development of microsatellite markers in potato and their use in phylogenetic and fingerprinting analyses. Genome, 2001, vol. 44, no. 1, p. 50-62. 
AVROVA, Anna O.; HYMAN, Lizbeth J.; TOTH, Rachel L. and TOTH, Ian K. Application of amplified fragment length polymorphism fingerprinting for taxonomy and identification of the soft rot bacteria Erwinia carotovora and Erwinia chrysanthemi. Applied and Environmental Microbiology, April 2002, vol. 68, no. 4, p. 1499-1508.

BORNET, B.; GORAGUER, F.; JOLY, G. and BRANCHARD, M. Genetic diversity in European and Argentinian cultivated potatoes (Solanum tuberosum subsp. tuberosum) detected by inter-simple sequence repeats (ISSRs). Genome, June 2002, vol. 45, no. 3, p. 481-484.

CONTRERAS, A.; BANSE, J.; FUENTEALBA, J.; ARUTA, C. and MANQUIAN, N. Germoplasma chileno de papas (Solanum tuberosum L.). Universidad Austral de Chile, Facultad de Ciencias Agrarias, Instituto de Producción Vegetal. Informe final-1980, 1981. 33 p.

FEDERICI, María Teresa; VAUGHAN, Duncan; TOMOOKA, Norihiko; KAGA, Akita; WANG WANG, Xin; DOI, Koji; FRANCIS, Marta; ZORRILLA, Gonzalo and SALDAIN, Nestor. Analysis of Uruguayan weedy rice genetic diversity using AFLP molecular markers. Electronic Journal of Biotechnology [online] 15 December 2001, vol. 4, no. 3 [cited 4 September 2006]. Available from Internet: http://www.ejbiotechnology.info/content/vol4/issue3/full/3. ISSN 0717-3458.

FURINI, A. and WUNDER, J. Analysis of eggplant (Solanum melongena) -related germplasm: morphological and AFLP data contribute to phylogenetic interpretations and germplasm utilization. Theoretical and Applied Genetics, January 2004, vol. 108, no. 2, p. 197-208.

HIJMANS, Robert J. and SPOONER, David M. Geographic distribution of wild potato species. American Journal of Botany, November 2001, vol. 88, no. 11, p. 2101-2112.

HUAMÁN, Z.; WILLIAMS, J.T.; SALHUANA, W. and VINCENT, N. Descriptors for the cultivated potato and for the maintenance and distribution of germoplasm collections. Consultative Group on Internacional Agricultural Research. Rome, International Board for Plant Genetic Resources (I.B.P.G.R.), 1977. 47 p.

ISENEGGER, Daniel A.; TAYLOR, Paul W.J.; FORD, Rebecca; FRANZ, Peter; MCGREGOR, Graeme R. and HUTCHINSON, James. DNA fingerprinting and genetic relationships of potato cultivars (Solanum tuberosum L.) commercially grown in Australia. Australian Journal of Agricultural Research, 2001, vol. 52, no. 9, p. 911-918.
KARDOLUS, Jouke P.; VAN ECK, Herman J. and VAN DEN BERG, Ronald G. The potencial of AFLPs in biosystematics: a first application in Solanum taxonomy (Solanaceae). Plant Systematics and Evolution, March 1998, vol. 210, no. 1-2, p. 87-103.

KIM, J.H.; JOUNG, H.; KIM, H.Y. and LIM, Y.P. Estimation of genetic variation and relationship in potato (Solanum tuberosum L.) cultivars using AFLP markers. American Journal of Potato Research, March 1998, vol. 75, no. 2, p. 107-102.

MAUGHAN, P.J.; SAGHAI MAROOF, M.A.; BUSS, G.R. and HUESTIS, G.M. Amplified fragment length polymorphism (AFLP) in soybean: species diversity, inheritance, and near-isogenic line analysis. Theoretical and Applied Genetics, August 1996, vol. 93, no. 3, p. 392401.

MARTINEZ, Liliana; CAVAGNARO, Pablo; MASUELLI, Ricardo and RODRIGUEZ, José. Evaluation of diversity among Argentine grapevine (Vitis vinifera L.) varietes using morphological data and AFLP markers. Electronic Journal of Biotechnology [online] 15 December 2003, vol. 6, no. 3 [cited 4 September 2006]. Available from Internet: http://www.ejbiotechnology.info/content/vol6/issue3/full/1 1/index.html. ISSN 0717-3458.

MCGREGOR, C.E.; GREYLING, M.M.; LAMBERT, C.A.; LOUW, J.H. and WARNICH, L. A comparative assessment of DNA fingerprinting techniques (RAPD, ISSR, AFLP and SSR) in tetraploid potato (Solanum tuberosum L.) germplasm. Euphytica, May 2000, vol. 113, no. 2, p. 135-144.

MCGREGOR, C.E.; VAN TREUREN, R.; HOEKSTRA, R. and VAN HINTUM, T.J. Analysis of the wild potato germplasm of the series Acaulia with AFLPs: implications for ex situ conservation. Theoretical and Applied Genetics, January 2002, vol. 104, no. 1, p. 146-156.

MILBOURNE, Dan; MEYER, Rhonda; BRADSHAW, John E.; BAIRD, Eileen; BONAR, Nicky; PROVAN, Jim; POWELL, Wayne and WAUGH, Robbie. Comparison of PCR-based marker system for the analysis of genetic relationships in cultivated potato. Molecular Breeding, April 1997, vol. 3, no. 2, p. 127-136.

MILBOURNE, D.; MEYER, R.C.; COLLINS, A.J.; RAMSAY, L.D.; GEBHARDT, C. and WAUGH, R. Isolation, characterisation and mapping of simple sequence repeat loci in potato. Molecular and General Genetics, August 1998, vol. 259, no. 3, p. 233-245. 
MILLER, Joseph T. and SPOONER, David M. Collapse of species boundaries in the wild potato Solanum brevicaule complex (Solanaceae, sp. Sect. Petota): molecular data. Plant Systematic and Evolution, March 1999, vol. 214, no. 1-4, p. 103-130.

ORTIZ, R. and HUAMAN, Z. Inheritance of morphological and tuber characteristics. In: BRADSHAW, J.E. and MACKAY, G.R. eds. Potato Genetics. CAB International, 1994, p. 263-279.

PAUL, S.; WACHIRA, F.N.; POWELL, W. and WAUGH, R. Diversity and genetic differentiation among populations of Indian and Kenyan tea (Camellia sinensis (L.) O. Kuntze) revealed by AFLP markers. Theoretical and Applied Genetics, February 1997, vol. 94, no. 2, p. 255263.

POWELL, Wayne; MORGANTE, Michele; ANDRE, Chaz; HANAFEY, Michael; VOGEL, Julie; TINGEY, Scott and RAFALSKI, Antoni. The comparison of RFLP, RAPD, AFLP and SSR (microsatellite) markers for germplasm analysis. Molecular Breeding, September 1996, vol. 2, no. 3, p. 225-238.

RAKER, Celeste M. and SPOONER, David M. Chilean tetraploid cultivated potato, Solanum tuberosum, is distinct from the Andean populations: microsatellite data. Crop Science, September-October 2002, vol. 42, no. 5, p. 14511458.

RITTER, Azpitarte. Aplicación de la biotecnología a la mejora genética de la patata. In: PATATA 2000. VitoriaGasteiz, España, 2000, p. 8.

RITTER, Enrique; LUCCA, Florencia; SÁNCHEZ, Isibene; RUIZ DE GALARRETA, José Ignacio; ARAGONÉS, Ana; CASTAÑÓN, Sonia; BRYAN, Glen; WAUGH, Robbie; LEFEBVRE, Veronique; ROUSSELLEBOURGOISE, Francoise; GEBHARDT, Christiane; VAN ECK, Herrman; VAN OS, Hans; TACO, Jesse and BAKKER, Jaap. Recursos genómicos en la papa y posibilidades de su explotación. Suplemento Revista Latinoamericana de la Papa, 2004, p. 2-18.

ROLDÁN-RUIZ, I.; VAN EUWIJK, F.A.; GILLILAND, T.J.; DUBREUIL, P.; DILLMANN, C.; LALLEMAND, J.; DE LOOSE, M. and BARIL, C.P. A comparative study of molecular and morphological methods of describing relationships between perennial ryegrass (Lolium Perenne L.) varieties. Theoretical and Applied Genetics, December 2001, vol. 103, no. 8, p. 1138-1150.

ROUPPE VAN DER VOORT, J.N.A.M.; VAN ECK, H.J.; DRAAISTRA, J.; VAN ZANDVORRT, P.M.; JACOBSEN, E. and BAKKER, J. An online catalogue of
AFLP markers covering the potato genome. Molecular Breeding, February 1998, vol. 4, no. 1, p. 73-77.

SAVELKOUL, P.H.M.; AARTS, H.J.M.; DE HAAS, J.; DIJKSHOORN, L.; DUIM, B.; OTSEN, M.; RADEMAKER, J.L.W.; SCHOULS, L. and LENSTRA, J.A. Amplified-Fragment Length Polymorphism Analysis: the State of an Art. Journal of Clinical Microbiology, October 1999, vol. 37, no. 10, p. 3083-3091.

SPOONER, David M.; PERALTA, Iris E. and KNAPP, Sandra. Comparison of AFLPs with other markers for phylogenetic inference in wild tomatoes (Solanum L. section Lycopersicon [Mill.] Wettst). Taxon, February 2005a, vol. 54, no. 1, p. 43-61.

SPOONER, David M.; MCLEAN, Karen; RAMSAY, Gavin; WAUGH, Robbie and BRYAN, Glenn J. A single domestication for potato based on multilocus amplified fragment length polymorphism genotyping. Proceedings of the National Academy of Sciences of the United States of America, October 2005b, vol. 102, no. 41, p. 14694-14699.

STEGEMANN, $\mathrm{H}$. and LOESCHECKE, V. Index Europäischer Kartoffelsorten; Bestimmung durch elecktrophoretische Spektren. Paul Parey, Berlín, 1976, 214 p.

STRAADT, I.K. and RASMUSSEN, O.S. AFLP analysis of Solanum phureja DNA introgressed into potato dihaploids. Plant Breeding, August 2003, vol. 122, no. 4, p. 352-356.

SUN, Genlou; WANG-PRUSKI, Gefu; MAYICH, Michael and DE JONG, Hielke. RAPD and pedigree-based genetic diversity estimates in cultivated diploid potato hybrids. Theoretical and Applied Genetics, June 2003, vol. 107, no. 1, p. 110-115.

VOS, Pieter; HOGERS, Rene; BLEEKER, Marjo; REIJANS, Martin; VAN DE LEE, Theo; HORNES, Miranda; FRITERS, Adrie; POT, Jerina; PALEMAN, Johan; KUIPER, Martin and ZABEAU, Marc. AFLP: A new technique for DNA fingerprinting. Nucleic Acids Research, 1995, vol. 23, no. 21, p. 4407-4414.

XU, Ru-Qiang; TOMOOKA, Norihiko and VAUGHAN, Duncan A. AFLP markers for characterizing the azuki bean complex. Crop Science, May-June 2000, vol. 40, no. 3, p. 808-815.

YEE, E.; KIDWELL, K.K.; SILLS, G.R. and LUMPKIN, T.A. Diversity among selected Vigna angularis (Azuki) accessions on the basis of RAPD and AFLP markers. Crop Science, January-February 1999, vol. 39, no. 1, p. 268-275. 